\title{
AMYLOIDOSIS IN STILL'S DISEASE
}

\author{
BY \\ J. A. JAMES and F. G. BOLTON \\ Late House Physicians, Royal United Hospital, Bath
}

Still (1897) first described the form of chronic polyarthritis of childhood now associated with his name, and six years later Whitman (1903) described two such cases complicated by amyloidosis, but since then few cases with post-mortem findings have been reported. Portis (1938) gave the findings in two fatal cases of Still's disease with amyloidosis, and was able to find five further cases among twelve post-mortem accounts in the literature. Trasoff and others (1944), in a review of the literature, collected 31 cases of amyloidosis in rheumatoid arthritis (nine below 16 years of age), all but five of which are known to have died. They also described a case of a patient suffering from Still's disease with amyloidosis who recovered, and they quote a similar case from Kennedy (1935). Further cases of this combination of diseases are recorded from the Massachusetts General Hospital (1945), by Coss and Boots (1946), and by Pickard (1947).

Dahlin (1949) has recently given an account of the pathology of amyloidosis. Amyloid disease complicating rheumatoid arthritis and Still's disease is of secondary type (Reimann and others, 1935) affecting mainly the kidneys, liver and spleen.

The case presented below is one of Still's disease of severe nature, with gross pericarditis and complicated by amyloidosis.

\section{Case Report}

The patient, a boy aged 3 years and 10 months, was admitted to hospital in February, 1947 , with a recurrent polyarthritis of 3 months' duration. He had had whooping-cough at 3 years and 6 months, but had otherwise been quite well, and there was no history of family illness, save for rheumatic fever in an uncle and two cousins. The present illness had the following features: There was a painful, flitting polyarthritis, particularly of the knees, wrists, ankles, and cervical spine, associated with severe general symptoms, notably anorexia, intermittent pyrexia to $102^{\circ} \mathrm{F}$. $\left(38 \cdot 9^{\circ} \mathrm{C}\right.$.), lymphatic gland enlargement, normochromic anaemia, and a markedly raised sedimentation rate. A week after admission a pericardial rub was heard, the heart having previously been clinically normal. The rub disappeared in a few days, but recurred 3 weeks and 5 weeks later, when it was heard for several days. At this period the child was very ill, with marked orthopnoea, and was obviously deteriorating, and he was taken home by his parents against medical advice, after 7 weeks in hospital. There had been no clinical response to aspirin in adequate dosage. 
$X$ ray of the chest showed general enlargement of the heart shadow; an electrocardiogram (leads I, II, and III) was normal; T.3 was inverted. There was slight proteinuria with no casts. $X$ ray of the joints showed periarticular soft tissue thickening without alteration in the joint spaces.

He was admitted to another hospital six weeks later with flexion contractures of the hips and knees, and intermittent pyrexia and anaemia. The heart was now clinically normal, and the liver and spleen were not palpable. Two weeks after admission a recurrence of the pericardial rub was noted with an apex beat in the anterior axillary line and a pulse of 140-160. This was a transitory incident, however, and he again improved a little. In view of the severe anaemia he was transfused with stored blood, his haemoglobin rising from 39 to 64 per cent. (Haldane). The limbs were splinted and a course of calciferol was given $(50,000$ international units bis die for 1 month), with no effect other than the production of a high blood calcium level of $13 \mathrm{mg} . / 100 \mathrm{ml}$. He was discharged unimproved in October, 1947.

Investigations.-Red blood count $2 \cdot 8$ million per c.mm.

Haemoglobin 39 per cent. (Haldane).

White blood count 24,100 (Polymorphs 21,700).

There were several white blood counts of approximately this figure during his illness. The urine contained a trace of protein and a few cellular and hyaline casts. Radiography demonstrated osteoporosis and delayed ossification of the carpal and tarsal bones with enlargement of the epiphyses.

He was re-admitted to hospital at the age of 5 , his condition having apparently remained unchanged for 5 months since his most recent discharge from hospital. Five weeks previously, however, after a crop of styes, he had developed diarrhoea and vomiting, and then swelling of the legs and abdomen. On admission he was found to have ascites, a greatly enlarged liver, and oedema of the legs, scrotum, and lumbosacral region.

The heart was enlarged, with an apical systolic murmur. Lymphatic glands were palpable in both axillae and in the neck, and the spleen was palpable. He was now found to have developed gross proteinuria with some hyaline casts. There was severe hypochromic anaemia: plasma proteins $4 \cdot 15 \mathrm{~g}$. per $100 \mathrm{ml}$. (fibrinogen $0 \cdot 33$, albumin $2 \cdot 86$, and globulin $0 \cdot 9.6 \mathrm{~g}$. per $100 \mathrm{ml}$.)

An electrocardiogram again showed an inversion of T.3.

High protein diet and blood transfusion were given with subsequent disappearance of oedema and ascites, but he developed a severe attack of varicella, became oedematous again, and died 18 months after the onset of his illness.

Post-Mortem Examination.-This confirmed the presence of marked periarticular thickening of many joints. The heart weighed $4 \frac{3}{4} \mathrm{oz}$. (135 g.); there was no evidence of valvular disease; the pericardial sac was obliterated by fibrous adhesions. The liver was greatly enlarged, weighing $3 \mathrm{lb}$. $10 \mathrm{oz}$. (1,644 g.); the spleen, weighing $5 \mathrm{oz}$. (142 g.) was bound down by adhesions. The kidneys weighed $7 \mathrm{oz}$. (198 g.) each; the capsules stripped easily.

Microscopic Examination.-This demonstrated diffuse amyloidosis and fatty change in the liver, deposits of amyloid in the Malpighian bodies and around the vessels of the spleen, and large deposits of amyloid in all the glomerular tufts of both kidneys (Figs 1 and 2, overleaf). Section of the mitral valve was normal: there were no Aschoff nodules, but some of the heart muscle fibres were indistinct and appeared to be infiltrated with amyloid. 


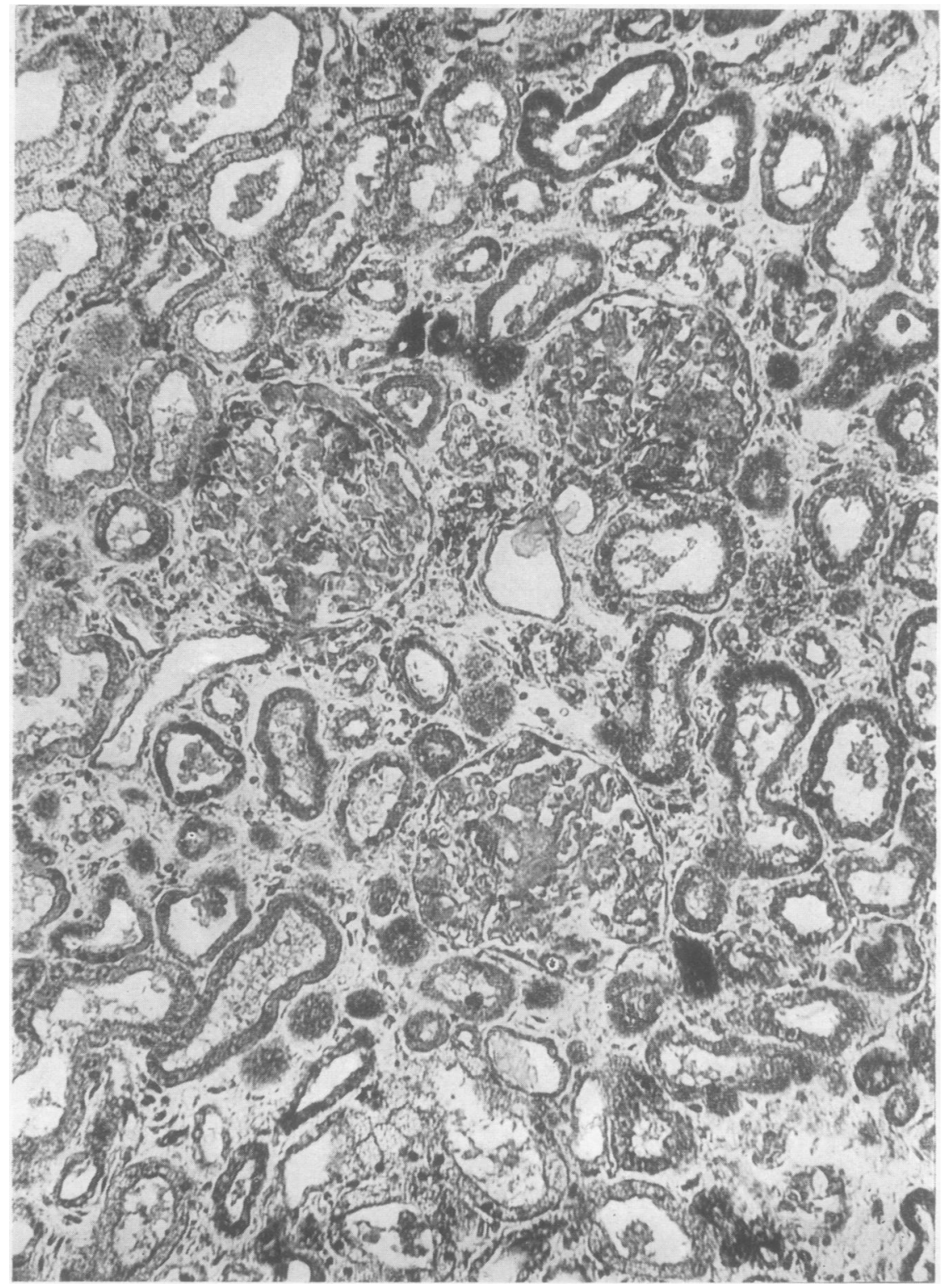

Fig. 1.-Kidney. Infiltration of glomeruli with amyloid. Methyl violet $(\times 200)$.

\section{Discussion}

This case exemplified most of the classical features of Still's disease, notably a chronic polyarthritis affecting the larger rather than smaller joints with periarticular thickening, enlargement of the lymph nodes, anaemia, and bouts of fever. Marked polymorphonuclear leucocytosis was noted on several occasions. Recurrent clinical pericarditis of a severe nature was a feature of this case, confirmed at 


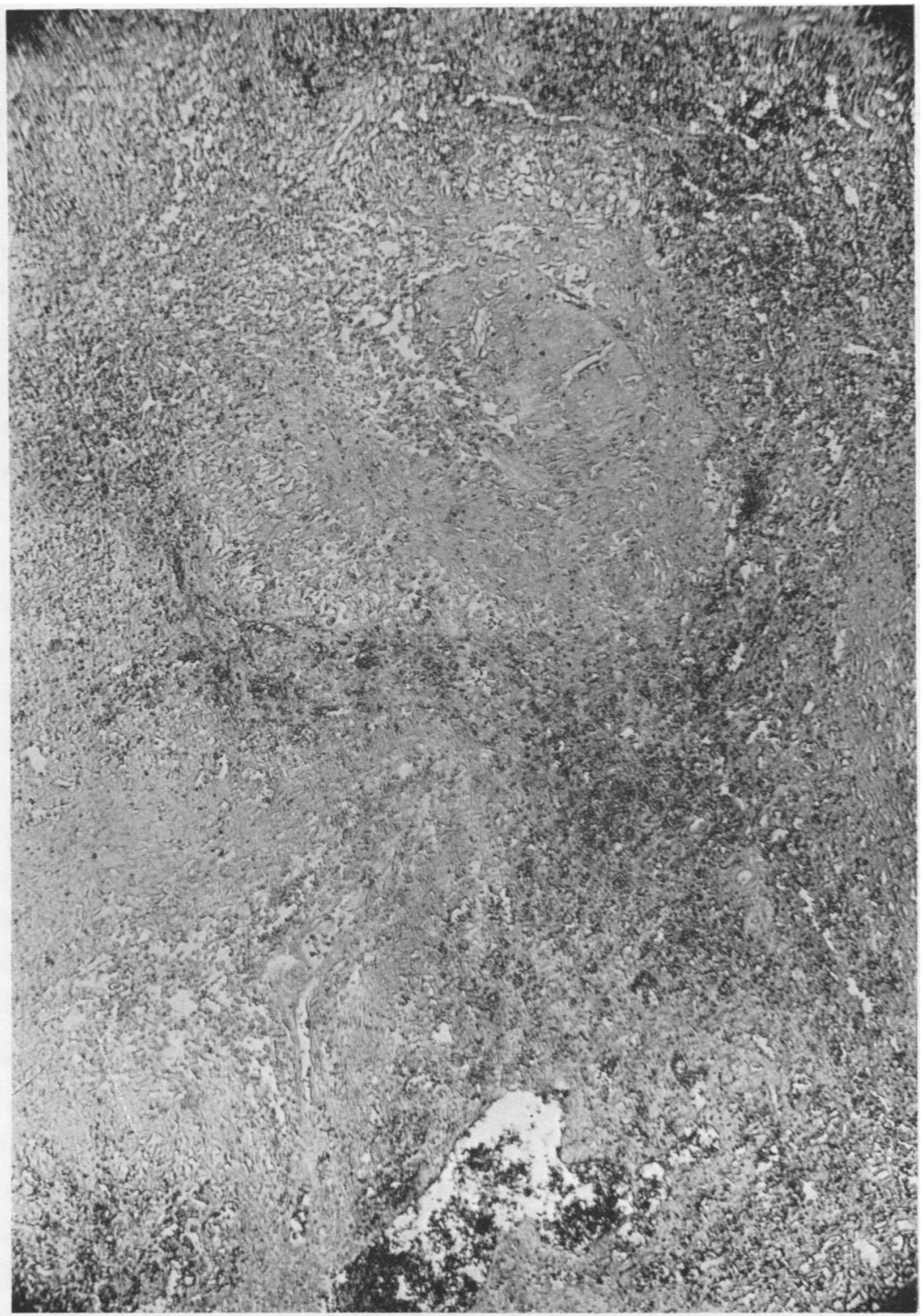

autopsy by an adherent pericardium. The three original cases of Still which came to autopsy each had an adherent pericardium, but pericarditis had not been noted clinically. The development of amyloid disease was suggested by gross hepatic enlargement, marked proteinuria, and oedema, though the congo red test was not performed. There was hypoproteinaemia without increase in the plasma globulin. Death appeared finally to be due to circulatory failure rather than 
uraemia, which is the usual cause of death from this type of secondary amyloidosis. Blood urea estimations had not, however, been carried out.

It is difficult to assess the incidence of this complication of Still's disease, but it is not common and follows only the more severe forms of the disease. Lush and others (1948) found one case of amyloidosis in 200 cases of rheumatoid arthritis of all ages; Pickard (1947) reports one death from amyloid disease in 35 cases of rheumatoid arthritis in children; Edström (1947) makes no mention of this complication in a review of 65 cases of juvenile rheumatoid arthritis in Sweden. The papers of Portis (1938) and of Trasoff and others (1944) suggest, however, that where Still's disease brings about death, amyloidosis is often the determining factor.

Jennings (1950) states that in the past 20 years enough cases of amyloidosis with rheumatoid arthritis have been described to suggest that this complication of rheumatic and rheumatoid disease will be recognized more often if it is always suspected when the condition lasts for more than one year and is associated with emaciation and anaemia, as in our case. Early diagnosis is of importance if the effect of liver or other therapy is to be assessed and gingival biopsy may be a simple and easy method of demonstrating amyloid tissue (Selikoff and others, 1949).

\section{Summary}

A case of Still's disease complicated by clinically recognized pericarditis and by amyloidosis is described. The post-mortem findings are summarized.

Our thanks are due to Prof. C. Bruce Perry and to Dr. J. Apley for permission to publish this case, and to Dr. Apley for his advice and criticism. The post-mortem and histological reports were made by Dr. H. J. Heathcote.

\section{REFERENCES}

Case No. 31212, in " Massachusetts General Hospital Case Records ”, ed. B. Castleman (1945). New Engl. J. Med., 232, 632.

Coss, J. A., and Boots, R. H. (1946). J. Pediat., 29, 143.

Dahlin, D. C. (1949). Ann. intern. Med., 31, 105.

Edström, G. (1947). Acta paediatr., Stockh., 34, 334.

Jennings, G. H. (1950). Brit. med. J., 1, 753.

Kennedy, W. R. (1935). Canad. med. Ass. J., 33, 385.

Lush, B., Chalmers, I. S., and Fletcher, E. (1948). Annals of the Rheumatic Diseases, 7, 225.

Pickard, N. S. (1947). Arch. intern. Med., 80, 771.

Portis, R. B. (1938). Amer. J. Dis. Child., 55, 1000.

Reimann, H. A., Koucky, R. F., Eklund, C. M. (1935). Amer. J. Path., 11, 977.

Selikoff, I. J., Paterson, N. J., and Herschfus, L. (1949). J. Amer. dent. Ass., 39, 159.

Still, G. F. (1897). Med.-chir. Trans., 80, 47. (Reprinted in Arch. Dis. Childh., 1941, 16, 156.)

Trasoff, A., Schneeberg, N., and Scarf, M. (1944). Arch. intern. Med., 74, 4.

Whitman, R. (1903). Med. Rec., N.Y., 63, 601.

\section{Dégénérescence Amylö̈de dans la Maladie de Still RÉSUMÉ}

On décrit un cas de maladie de Still, compliquée de péricardite reconnue en clinique et de dégénérescence amyloïde. On présente un résumé des résultats d'autopsie.

\section{Amiloidosis en la Enfermedad de Still Sumario}

Se describe un caso de la enfermedad de Still complicado con pericarditis y con amiloidosis, clinicamente reconocidas. Se presenta un resumen de los resultados de autopsia. 